\title{
Preliminary classification of
}

Shinnery oak Communities in southeastern New Mexico

Brian Martin and Kirk McDaniel ${ }^{1}$

classification is defined as the grouping or clustering of objects based upon their resemblance. In ecology, Gauch (1982) recognized three purposes for classification: to summarize large, complex sets of data, to aid in environmental interpretation of patterns of community variation, and to refine models of community structure. Several strategies have been developed for classifying communities, however, a complete description of each of these is beyond the scope of this report. The reader is referred to excellent reviews of classification strategies and theory by Whittaker (1978), Gauch (1981), Ratliff and Pieper (1982), and Ludwig and Reynolds (1988).

The objective of this study was to develop a vegetation classification of shinnery oak communities in, southeastern New Mexico. The vegetation key and legend described herein is preliminary and subject to revision upon further computer analysis of field data.

\section{Classification of Shinnery oak Vegetation}

Shinnery oak communities have variously been described and classified across their range. In Oklahoma, wiedeman and Penfound (1960) described a "shin" oak complex dominated by shinnery oak and various scrub oak species. Other woody plants reported to ${ }^{1}$ Former graduate student and Professor, Department of Animal and Range Sciences, New Mexico State University. 
occur in communities described by wiedeman and Penfound, included sand sage, skunkbrush, western hackberry, yucca, and grapes. Grasses included primarily short and midgrass species, such as little bluestem, three-awns, hairy and blue grama, sandburs, and sand dropseed.

Shinnery oak communities in New Mexico have been described by several researchers conducting studies in this vegetation type. Davis et al. (1979) and Davis et al. (1981) described shinnery vegetation while researching lesser prairie chicken habitat requirements in the Mescalero Sands in northern Chaves county and around the town of Milnesand in Roosevelt county. A shinnery oaktallgrass type was described in the Mescalero Sands. This type was further divided into three subtypes 1, 2 and 3 . These subtypes were defined according to prominence of sand bluestem, with subtype 1 possessing the greatest basal area and subtype 3 the least. Cover of shinnery oak was similar between subtypes 1 and 2 , whereas subtype 3 had higher cover. Common associate grasses included purple three-awn, hairy grama, little bluestem, and Hall's panicum.

Three shinnery oak types were recognized near Milnesand by Davis et al. (1981), including shinnery oak-bluestem, shinnery oak-midgrass, and sandhills. The shinnery oak-bluestem type was dominated by shinnery oak with an interspersion of grasses, primarily little and sand bluestem. The shinnery oak-midgrass type was comprised mainly of shinnery oak and several midgrass species, including gramas, dropseeds, and three-awns. The sandhills type was 
characterized as active duneland vegetated primarily by shinnery oak with a sparse grass cover consisting of purple three-awn, hairy grama, fall witchgrass, and sand paspalum.

In Texas, shinnery oak communities were studied and classified by Sullivan (1980), who recognized three community types, designated A, B, and C. In addition, communities were further delineated and described within each of these types. Community type A, was characterized by active dune land and was considered an early succession and unstable community. Three sub-communities were recognized within this type: shinnery oak/Harvard panicum-giant sandreed, shinnery oak/Harvard panicum-giant dropseed, and shinnery oak/giant dropseed-Harvard panicum. Vegetation in these communities consisted primarily of shinnery oak, yucca, various tallgrasses, and annual forbs. Cover ranged from less than $5 \%$ in the shinnery oak/Harvard panicum-giant sandreed community to $80 \%$ in the shinnery oak/giant sandreed-Harvard panicum community. Soils were primarily Kermit fine sands.

Community type $\mathrm{B}$ was characterized by a level to undulating topography with occasional small blowouts. Numerous grass and forb species were present in this community type, however, shinnery oak was the most prominent species, forming large extensive mats, ranging in cover from 20 to $77 \%$. Two communities were recognized: shinnery oak/sand dropseed-giant dropseed community, which occurred on generally flat topography, and shinnery oak/giant dropseed community, which occurred on undulating to hilly topography ranging 
in slope from 5 to $30 \%$. These communities occurred on Tivioli, Brownfield, Jalmar and Penwell fine sands.

Community type $c$ was distinguished by the presence of honey mesquite. Only one community was recognized within this type, honey mesquite/shinnery oak/sand dropseed, however, several phases were delineated within this community. Differences in phases was related to depth of clay accumulation in the soil, with shallower, less sandy soils supporting increased densities of mesquite. Shinnery oak often occurred in broken motts in this community type and canopy cover was relatively low, ranging from 6 to $28 \%$. Mesquite cover ranged from 8 to $16 \%$ in lower rainfall areas to 4 to $5 \%$ in higher rainfall areas. Soils were numerous, including: Brownfield, Triomas, Jalmar fine sands, Amarillo, Springer, Gomez loamy fine sands, and Amarillo fine sandy loam.

\section{STUDY AREA}

Research was conducted in Chaves, Eddy, Lea and Roosevelt counties of southeastern New Mexico. Climate of southeastern New Mexico is semi-arid, characterized by distinct seasons, wide ranges of diurnal temperatures, and plentiful sunshine. Average annual temperatures range from $14 \mathrm{C}$ in northern chaves county to $16 \mathrm{C}$ in Eddy county. Precipitation ranges from 25 to $41 \mathrm{~cm}$, with a general gradient of increased precipitation from the west to northeast. Nearly $85 \%$ of the precipitation falls from May to 
Table 1. Soil associations supporting shinnery oak communities in southeastern New .Mexico.

\begin{tabular}{|c|c|c|c|c|}
\hline Association & County & $\begin{array}{l}\text { Percent of } \\
\text { Survev Arca }\end{array}$ & $\underline{\text { Soil Series }}$ & Percent \\
\hline $\begin{array}{l}\text { Nutivoli-Jalmar- } \\
\text { Faskin }\end{array}$ & $\begin{array}{l}\text { Chaves } \\
\text { (North) }\end{array}$ & 1 & $\begin{array}{l}\text { Nutivoli } \\
\text { Jalmar } \\
\text { Faskin } \\
\text { Other soils }\end{array}$ & $\begin{array}{l}38 \\
24 \\
22 \\
16\end{array}$ \\
\hline $\begin{array}{l}\text { Faskin-Roswell- } \\
\text { Jalmar }\end{array}$ & $\begin{array}{l}\text { Chaves } \\
\text { (North) }\end{array}$ & 25 & $\begin{array}{l}\text { Faskin } \\
\text { Roswell } \\
\text { Jalmar } \\
\text { Other soils }\end{array}$ & $\begin{array}{l}37 \\
25 \\
14 \\
24\end{array}$ \\
\hline $\begin{array}{l}\text { Roswell-Faskin- } \\
\text { Jalmar }\end{array}$ & $\begin{array}{l}\text { Chaves } \\
\text { (South) }\end{array}$ & 10 & $\begin{array}{l}\text { Roswell } \\
\text { Faskin } \\
\text { Jalmar } \\
\text { Other soils } \\
\text {-Ima } \\
\text {-Simona } \\
\text { - Malstrone } \\
\text {-Dune land }\end{array}$ & $\begin{array}{l}40 \\
25 \\
15 \\
20\end{array}$ \\
\hline $\begin{array}{l}\text { Berino-Pintura- } \\
\text { Pajarito }\end{array}$ & $\begin{array}{l}\text { Chaves } \\
\text { (South) }\end{array}$ & 5 & $\begin{array}{l}\text { Berino } \\
\text { Pintura } \\
\text { Pajarito } \\
\text { Other soils } \\
\text {-Cacique } \\
\text {-Tencee } \\
\text {-Simona } \\
\text {-Jal } \\
\text {-Alma }\end{array}$ & $\begin{array}{l}40 \\
10 \\
10 \\
40\end{array}$ \\
\hline Kermit-Berino & Eddy & 17 & $\begin{array}{l}\text { Kermit } \\
\text { Berino } \\
\text { Other soils } \\
\text {-Pajarito } \\
\text {-Wink } \\
\text { - Cacique } \\
\text {-Tonueo } \\
\text {-Dune land }\end{array}$ & $\begin{array}{l}60 \\
30 \\
10\end{array}$ \\
\hline $\begin{array}{l}\text { Brownfield-Patricia- } \\
\text { Tivoli }\end{array}$ & Lea & 6 & $\begin{array}{l}\text { Brownfield } \\
\text { Patrieia } \\
\text { Tivoli } \\
\text { Other soils } \\
\text {-Springer } \\
\text {-Gomez } \\
\text {-Amarillo } \\
\text {-Arvana } \\
\text {-Sharvana }\end{array}$ & $\begin{array}{l}30 \\
20 \\
15 \\
35\end{array}$ \\
\hline
\end{tabular}


Table \& continued

\begin{tabular}{|c|c|c|c|c|}
\hline $\begin{array}{l}\text { Pyote-Maljamar- } \\
\text { Kermit }\end{array}$ & Lea & 26 & $\begin{array}{l}\text { Pyote } \\
\text { Mialjamar } \\
\text { Kermit } \\
\text { Other soils } \\
\text {-Palomas } \\
\text { - Irink } \\
\text { - Largo } \\
\text { - Pajarito } \\
\text {-Tonuco }\end{array}$ & $\begin{array}{l}30 \\
20 \\
15 \\
35\end{array}$ \\
\hline $\begin{array}{l}\text { Tivoli-Springer- } \\
\text { Brownfield }\end{array}$ & Roosevelt & 15 & $\begin{array}{l}\text { Tivoli } \\
\text { Springer } \\
\text { Brownfield } \\
\text { Arch } \\
\text { Potter } \\
\end{array}$ & NA \\
\hline
\end{tabular}


October, corresponding with the growing season. Evaporation ranges from 244 to $279 \mathrm{~cm}$ per year.

Shinnery oak communities occur on numerous soil associations in southeastern New Mexico (Table 1). Complete descriptions of each soil series occurring in the formentioned associations are available in Soil Conservation service soil surveys of Chaves, Eddy, Lea, and Roosevelt counties (USDA 1967, 1971, 1974, 1980a, 1980b, 1967).

Generally, the associations supporting shinnery oak communities are characterized by deep sandy and fine sand soils that are well to excessively drained. Permeability is moderate to rapid. The soils are highly susceptible to wind and water erosion, and actively moving dunes are present. Topography ranges from level to rolling, with slopes varying from 0 to 30 percent (USDA 1967, $1971,1974,1980 \mathrm{a}, 1980 \mathrm{~b})$.

\section{METHODS}

Sampling for classification of shinnery oak communities was completed in two phases. In August 1988, 194 shinnery oak stands were extensively sampled along a preplanned reconnaissance route. The goal of the reconnaissance was to familiarize the researcher with the study area and to formulate sampling methodology for the following growing season.

Location of the route was determined by potential of soils to support shinnery oak communities and the accessibility of those areas to a two wheel drive vehicle. Sample sites were located 
approximately $1.6 \mathrm{~km}$ apart along the route where shinnery oak was present. At each site all flowering and prominent nonflowering species were recorded and assigned absolute cover class (Daubenmire 1959) and prominence (Poulton 1970) values. In addition, topographic position of the site, slope and aspect, and color of soil were noted.

Based upon the data collected during the reconnaissance, three major shinnery oak vegetation types were recognized: shinnery oak, tebuthiuron treated shinnery oak, and dune complex. In August and September 1989, shinnery oak and tebuthiuron treated shinnery oak areas were intensively sampled, whereas dune complex areas were extensively sampled as in 1988. Sample sites of the shinnery oak type were located $3.2 \mathrm{~km}$ apart, while tebuthiuron treated shinnery oak and dune complex areas were sampled when possible. At each stopping location a single plot was located randomly $100 \mathrm{~m}$ in one of eight potential directions (N, NW, W, SW, S, SE, E, NE).

Intensive sampling was conducted in $10 \times 20 \mathrm{~m}^{2}$ macroplots.

Four $20 \mathrm{~m}$ transect lines were located $2.5 \mathrm{~m}$ apart in each macroplot, with five $.5 \mathrm{~m}^{2}$ rectangular microplots equidistantly located along each transect. Within each microplot several vegetation parameters were estimated or measured, including: foliar cover of grasses, forbs, shinnery oak, and snakeweed, ground cover of litter and bare ground, density of shinnery oak stems, and maximum height of shinnery oak. Foliar and ground cover was ocularly estimated by a single observer in a nested frame. Species 
with cover less than $1 \%$ were assigned a value of trace (T). Density of shinnery oak stems was measured by counting individual stems on the left half of each frame, while maximum height was determined by measuring the tallest stem on the left half of the frame. In addition to the vegetation parameters recorded in the microplots, canopy cover of mesquite, sand sagebrush, yucca, and javelina bush occuring in the macroplot was measured and number of plants tabulated. Species occurring in the area, but not previously noted in the collection of data were listed as present and assigned a value of (P). Also, all species recorded were assigned a prominence value, based upon the index developed by Poulton (1970). Finally, for each macroplot, elevation, slope and aspect, and soils were noted. Soils were determined from soil surveys conducted by the Soil Conservation service.

Data collected during the 1989 field season was analyzed with Bray-Curtis (1956) percent dissimilarity. Stands were compared based upon mean vegetation cover data. compilation and mathematical analysis was achieved by use of the program CLUSTAR. Following completion of data analysis, the program arranged stands in a hierarchical, agglomerative dendogram, according to similarity of stand vegetation. Communities were recognized by objectively breaking the resulting dendogram into logical divisions. During the course of identification, stands which did not fit well into a respective community were moved to an appropriate one. Movement was minimized as much as possible to maintain the mathematical integrity of the analysis. Stands which did not fit any of the 
communities were identified as potential communities in which insufficient data were collected to designate a separate community. Such stands were classified as stand/community and briefly described separately in the results section. 
RESULTS

Key to shinnery oak plant communities

1a. Bouteloua hirsuta dominates the understory, Quercus harvardii dispersed.

... Prosopis glandulosa/Quercus havardii/Bouteloua hirsutaAristida purpurea community

1b. Bouteloua hirsuta not dominant, Quercus havardii may or may not be dispersed.

... go to 2 .

2a. Prosopis glandulosa dominates, Quercus havardii a minor understory species.

... Prosopis glandulosa/Quercus havardii/Aristida purpurea-sporobolus community

2b. Prosopis glandulosa may or may not be present but is not the dominant woody species.

... go to 3 .

3a. Andropogon hallii or Schizachyrium scoparium a major

component of the herbaceous layer.

... go to 4 .

3b. Andropogon hallii or Schizachyrium scoparium may be present, but not abundant. Primary species are Aristida or

Sporobolus spp.

... go to 6 .

4a. Gutierrezia sarothrae a prominant woody species, primary grasses are Schizachyrium scoparium and Aristida purpurea

... Quercus havardii/Gutierrezia sarothrae/Aristida

purpurea-Schizachyrium scoparium community.

4b. Gutierrezia sarothrae may be present, but only as a minor species. Primary grasses are tallgrasses or Aristida ... go to 5 .

5a. Schizachyrium scoparium and Andropogon hallii codominant species. Shinnery oak cover greater than $30 \%$.

... Quercus havardii/Schizachyrium scopariumAndropogon hallii community

5b. Andropogon halli or Schizachyrium scoparium co-dominates with Aristida purpurea. Shinnery oak cover less than $25 \%$.

... Quercus havardii/Aristida purpurea-Andropogon hallii community 
6a. Shinnery oak cover greater than $35 \%$.

... Quercus havardii/Aristida purpurea-Sporobolus

cryptandrus community

6b. Shinnery oak cover less than $25 \%$.

... Quercus havardii/Aristida purpurea-Lepteloma cognatum community

\section{Descriptive Legend to Shinnery oak Community Types}

Prosopis glandulosa/ouercus havardii/Bouteloua hirsuta-Aristida purpurea

This type is distinguish by a dominance of hairy grama, which gives the community a shortgrass appearance. The five samples included in this type were in southern Roosevelt, northern Lea, and eastern Chaves county.

Shinnery oak is the primary woody species in this community type, however, mean density $\left(6.8\right.$ stems $\left./ \mathrm{m}^{2}\right)$ and cover $(9.8 \%)$ are relatively low. Shinnery oak grows primarily in isolated motts or sparsely throughout the community. Snakeweed and mesquite are commonly associated species, however, several species may be present, including: Acacia greggi, Chryosthamnus pulchellus, opuntia polyacantha, and plains yucca. Hairy grama is the dominant herbaceous species, with a mean coverage of $11.9 \%$. Purple threeawn, sand dropseed, fall witchgrass, and sand paspalum are associated species. Several forbs may be present, including Commelina erecta, Commandra pallida, and cryptantha jamessii.

Major species of this community and their constancy and mean coverage percentages are as follows: 
Species

Aristida purpurea

Bouteloua curtipendula

Bouteloua hirsuta

Leptoloma cognatum

Paspalum setaceum

Sporobolus cryptandrus

Gutierrezia sarothrae

Prosopis glandulosa

Quercus havardii

\section{Constancy}

(\%)

100

100

100

100

100

100

100

80

100
Mean Coverage

(\%)

4.9

0.9

11.9

1. 4

1.1

1.6

4. 4

2. 6

9.8

Bare ground

Litter

33.8

48.1

Soils of this community are higher in silt and clay content than other communities described. Textures are loamy fine sand and fine sandy loam. Stands were recorded on the following soil mapping units: Amarillo-Arvana loamy fine sands association, Amarillo loamy fine sand, Amarillo find sandy loam, Arvana loamy fine sand, and Faskin, moist-Douro association. Topography is level.

Prosopis glandulosa/ouercus harvardii/Aristida purpurea-Sporobolus cryptandrus

This community type is among the most xeric studied, supporting isolated patches of vegetation within large areas of bare ground. This community can be distinguished by the dominant mesquite strata and scattered shinnery oak understory. This community generally has few herbaceous species. As few as three grasses were recorded with forbs often being absent. Samples were located in Lea, Eddy, and Chaves counties. 
In constrast to all other shinnery oak community types, mesquite dominates among woody species in this community. Density of mesquite ranges from 50 to 250 plants/ha. Shinnery oak is isolated in small pockets $\left(5.3\right.$ stems $\left./ \mathrm{m}^{2}\right)$, or widely dispersed. Canopy height of shinnery oak varies greatly throughout the stand. Mean heights in the sample stands ranged from 23.1 to $105 \mathrm{~cm}$, with. the mean maximum height being $39.5 \mathrm{~cm}$. Other shrubs present include plains yucca and snakeweed. Purple three-awn is the dominant graminoid, ranging in cover from less than $1.0 \%$ to $5.0 \%$. Sand dropseed was the only other graminoid with a constancy of $60 \%$. other grasses that may be locally abundant include black grama, fall witchgrass, and sandbur. Common forbs include croton pottsii and Ambrosia psilostachya.

Constancy and mean coverage percentages of major species are as follows:

\section{Species}

Aristida purpurea Sporobolus cryptandrus Prosopis glandulosa Quercus havardii Yucca campestris

Bare ground Litter

\section{Constancy}

(\%)

93

87

100

100

87

\section{Mean Coverage}

(\%)

1.6

0.7

10.7

6.2

0.6

41.5

47.6

Samples were located on find sand, and loamy find sand textures. Soil mapping units included: Berino complex, Faskin find sand, Kermit Palomas fine sands, Kermit soils and Dune land, Maljamar and Palomas find sands, Pajarito loamy find sand, Pyote 
and Maljama fine sands, and Pyote soils and Dune land. Topography is primarily level to gently rolling, however, this community may occur on undulating dunes with slopes of $15 \%$.

\section{Quercus havardii/Aristida purpurea-Leptoloma cognatum}

Distinguished by an open shinnery oak canopy with a herbaceous layer dominated by midgrass species, this community was the most common and widely sampled, occuring throughout the sample area with the exception of Roosevelt county. Considerable variation in cover values of dominant species was observed within this community type, therefore, several phases were recognized. Differences in species composition between phases are relatively small, and appear largely due to past grazing practices.

overall this types is characterized by a relatively open shinnery oak stand (cover of $12.7 \%$ ). The canopy is uniform in distribution, interrupted ocassionally by blowouts and small patches of bare ground. Mesquite may make up a substantial portion of the canopy in locations, but is often wide spread to absent. Yucca campestris and Artemesia filifolia are minor shrubs commonly found in stands. The herbaceous layer is dominated by purple three-awn, fall witchgrass, and sand dropseed, with Cenchus incertus and black grama being locally important. Forbs are a minor component of the community, being limited both in composition and coverage. Constancy and mean coverage values for the community are list below. 


\section{Species}

Aristida purpurea

Lepteloma cognatum

sporobolus cryptandrus

Quercus havardii

Yucca campestris

Bare ground

Litter

\section{Constancy}

(\%)

98

90

87

100

80

\section{Mean Coverage}

(\%)

2. 0

1. 0

0.7

12.7

0.4

Three phases are recognized within this community. The first of these is a Prosopis glandulosa/Quercus havardii-Artemesia fillifolia/Aristida purpurea-Leptoloma cognatum phase. The "woodiest" of the phases, mesquite forms a tall shrub statum with shinnery oak, sand sagebrush, yucca, and snakeweed occuring as a understory shrub layer. Purple three-awn and fall witchgrass codominate in the herbaceous layer. Common associated species include: sand dropseed, sandbur, and black grama. Constancy and mean cover values of this phase are provided below:

\section{Species}

Aristida purpurea Lepteloma cognatum Sporobolus cryptandrus Artemesia filifolia Prosopis glandulosa Quercus havardii Yucca campestris

Bare ground Litter

\section{Constancy}

(\%)

100

86

100

71

100

100

71

\begin{tabular}{c} 
Mean Coverage \\
\hline$(\%)$ \\
1.9 \\
1.3 \\
0.7 \\
1.3 \\
5.4 \\
12.0 \\
0.4
\end{tabular}

38.2

57.9

The second phase is Quercus havardii/Bouteloua eriopodaAristida purpurea. Shinnery oak is the primary shrub in this phase. Mesquite, yucca, and Ephedra antisyphilitica are minor associated shrub species. This phase is distinguished by the 
abundance and constancy of black grama. Secondary grass species include purple three-awn, and sand dropseed. Species constancy and mean coverage values are listed below.

\begin{tabular}{|c|c|c|}
\hline Species & $\frac{\text { Constancy }}{(\%)}$ & $\frac{\text { Mean Coverage }}{(\%)}$ \\
\hline Aristida purpurea & 100 & 1.9 \\
\hline Bouteloua eriopoda & 100 & 3.6 \\
\hline Lepteloma cognatum & 75 & 0.1 \\
\hline sporobolus cryptandrus & 100 & 1.4 \\
\hline Prosopis glandulosa & 75 & 0.3 \\
\hline Quercus havardii & 100 & 10.8 \\
\hline Yucca campestris & 75 & 0.4 \\
\hline Bare ground & & 36.7 \\
\hline Litter & & 58.1 \\
\hline
\end{tabular}

The third phase, Quercus havardii/Aristida purpurea-Leptoloma cognatum, had the greatest canopy coverage of shinnery oak and purple three-awn, whereas mesquite was uncommon to absent. Fall witchgrass and sand dropseed are secondary grass species. Species occurring in this phase with a constancy value greater than $60 \%$ include:

\section{Species}

Aristiada purpurea Lepteloma cognatum sporobolus cryptandrus Quercus havardii Yucca campestris

Bare ground Litter

\section{Constancy}

(\%)

98

82

83

100

79
Mean Coverage

(\%)

2.0

1.0

0.6

12.8

0.3

Topography of the community ranges from level to undulating dunes with slopes up to $30 \%$. Soils are primarily classified as sandy, loamy fine sand, and find sands. Soil mapping units where stands were sampled include: Berino complex, Faskin-Malstrom association, Kermit-Palomas find sands, Kermit soils and Dune land, 
Pyote loamy find sand, Pyote and Maljamar fine sands, Pyote soils and Dune land, Roswell fine sand, Roswell-Jalmar fine sands, and Stromal-Pyote fine sands.

Quercus havardii/Schizachyrium scoparium-Andropogon hallii

This community type occurs in northern Lea and southern Roosevelt counties in the Southern Great Plains physiographic region. The abundance of little and sand bluestem gives this community a tallgrass appearance with the shinnery oak substratum.

Shinnery oak is the primary woody species, with a mean coverage of $31.5 \%$. The canopy is relatively tall (mean maximum height of $40.8 \mathrm{~cm}$ ) and dense $\left(14\right.$ stems $\left./ \mathrm{m}^{2}\right)$. Yucca and snakeweed are both minor, common species. The herbaceous layer is dominated by little bluestem, with sand bluestem, sand paspalum, hairy grama, and purple three-awn being important associate species. Forbs are relatively abundant in this community with a mean average of nearly 5 species per stand. The most common species include: Commelina erecta, oryptantha jamesii, and commandra pallida.

Major species of this community and their constancy and mean coverage values are as follows: 
Species

Andropogon hallii

Aristida purpurea

Bouteloua hirsuta

Eragrostis secundiflora

Leptoloma cognatum

Paspalum setaceum

Schizabhyrium scoparium

Sporobolus cryptandrus

Guterrezia sarothrae

Quercus havardii

Yucca campestris

Bare ground

Litter
Constancy

(\%)

$$
100
$$

100

100

60

60

100

100

100

60

100

100
Mean Coverage

(\%)

1.8

1.2

1.4

0.4

0.1

1.8

5.2

0.4

0.1

31.5

0.2

Soils textures are entirely fine sands, however, this type occurs on various soil mapping units, including: Amarillo-Gomez, brownfield, Brownfield-Patricia, and Tivoli find sands. Topography is level to gently sloping with occassional, small, stabilized dunes.

Quercus havardii/Gusa/Schizachyrium scoparium-Aristida purpurea

This community is distinguished by an abundance of snakeweed. The community has an appearance of a relatively open shinnery oak canopy with a mixed grass herbaceous layer. Number of species per stand was greatest in this community, with a mean of 20 . Sample stands were located in northern Lea, eastern Chaves, and southern Roosevelt counties.

The shinnery oak canopy is moderate in coverage (18.6\%) and density $\left(11.2\right.$ stems $\left./ \mathrm{m}^{2}\right)$. Most notable among the woody species is the abundance of snakeweed, which has a cover of 3.6\%. This represented the highest mean coverage of snakeweed for communities 
described. The herbaceious layer is co-dominated by little bluestem and purple three-awn. Numerous associated species occur in the community, with seven other grasses having constancy values of $60 \%$. Forbs are relatively abundant, averaging seven species per stand. Among the most common are Commandra pallids, Ambrosia psilostachya, and cryptantha jamesii.

\section{Species}

Andropogon hallii

Aristida purpurea

Bouteloua curtipendula

Bouteloua hirsuta

Eragrostis secundiflora

Leptoloma cognatum

Paspalum setaceum

Schizachyrium scoparium

Sporobolus crytandrus

Gusa

Quercus havardii

Commandra pallida

Bare ground

Litter

\section{Constancy}

(q)

75

100

75

100

100

75

100

100

100

100

100

100

\begin{tabular}{c} 
Mean Coverage \\
\hline$(\%)$ \\
1.0 \\
3.4 \\
0.4 \\
1.5 \\
1.3 \\
0.2 \\
1.9 \\
3.6 \\
0.5 \\
3.6 \\
18.6 \\
2.0
\end{tabular}

30.6

60.4

Soils of this community type consist of three different textures, find sand, loamy fine sand, and find sandy loam. Soil mapping units include: Amarillo loamy fine sand, Brownfield fine sand, Douro-Faskin, moist association, and Tivoli find sand. Topography is level to gently rolling.

Quercus havardii/Aristida purpurea-sporobolus cryptandrus

This community type occurs primarily on localized dunes in southern Roosevell and northern Lea counties. Interspersed in Quercus havardii/Schizachyrium scoparium-Andropogon halli and Quercus havardi-Gutierrezia sarothrae/Schizachyrium scopariumAristida purpurea types, this community is distinguished by an 
abundance of shinnery oak and limited coverage of grasses.

Shinnery oak occurs as a dense $\left(26: 8\right.$ stems $\left./ \mathrm{m}^{2}\right)$ closed canopy in this community. Cover in the four stands ranged from $41 \%$ to 55\%. Shinnery oak dominates almost to the exclusion of a herbaceous component. Purple three-awn is the most prevelent graminoid, with little bluestem, sand dropseed, and sand paspalum being common associate species. Based upon the location of this community, it would appear tallgrass species have been greatly reduced by past grazing. Tallgrass species, sand bluestem and giant dropseed, occasionally occur as minor components. Forbs are of minor importance in this community, with a mean of 2 species per sample stand.

Constancy and mean coverage values of this community are as follows:

Species

Aristida purpurea

Paspalum setacerum

Scizachyrium scoparium

sporobolus cryptandrus

Quercus havardii

Bare ground

Litter
Constancy

(\%)

100

75

75

100

100

$(\%)$

5

5

(1)

0.3

0.6
0.6

46.0

30.4

66.2

Soils were fine sand and loamy find sand in texture. Soil mapping units include: Gomez loamy fine sand, Roswell-Jalmar fine sands, and Tivoli fine sand. Topography was rolling to undurlating with slopes ranging from $7 \%$ to $30 \%$. Small blowouts were present in some of the stands. 
Quercuse havardii/Aristida purpurea-Andropogon hallii

This community is an innerspersion of tall and mixed grass species. Considerable variation in abundance of grasses may occur within this community, apparently due to grazing influence. In appearance shinnery oak dominates the landscape with sand and little bluestem culms rising through the canopy. This community was primarily sampled in the Mescalero Sands area in Chaves county, but stands were noted as far as southern Lea and Roosevelt counties.

The shineery oak canopy is evenly distributed throughout the community, being interupted by ocassional blowouts, which may be several meters in circumference. Density $\left(11.6\right.$ stems $\left./ \mathrm{m}^{2}\right)$ and height of canopy $(35.9 \mathrm{~cm})$ are approximately in the middle of the range exhibited throughout the study area. Mesquite is generally absent, however, it may be found in very localized areas. Other common shrubs include yucca and sand sagebrush. Composition of grasses is relatively constant in this community, with sand and little bluestem, purple three-awn, hairy grama, and sand paspalum consistantly bieng the most abundant species. As noted previously, cover values vary gretly, with sand and little bluestem dominating in climax stands, as identified in SCS ecological monitoring guides. Purple three-awn is most prevalent in areas of lower ecological condition. Constancy and cover values of species in this stand are listed below. 
Species

Andropogon halli

Aristida purpurea

Bouteloua hirsuta

Paspalum setaceum

Schizachyrium scoparium

Sporobolus cryptandrus

Artemesia filifolia

Quercus havardii

Yucca campestris

Bare ground

Litter
Constancy

(\%)

93

100

78

93

78

100

64

100

86
Mean Coverage

(\%)

1.0

1.8

1.5

0.5

2.1

0.4

0.7

20.7

0.4

36.5

57.2

Samples in this community occured on fine sand texture soils of the following soil mapping units: Brownfield fine sand, FaskinMalstrom association, Jalmar-Roswell-Pyote association, Kermit soils and Dune land, Roswell fine sand, Roswell-Jalmar fine sands, and Stromal-Faskin-Malstrom fine sands. Topography varied from level to undulating dunes with slopes of $17 \%$. Blowouts are a common physical feature of this community.

OUTLIER STANDS/COMMUNITIES

ouercus havardii/schizachyrium scoparium-Panicum havardii

This stand was considered as a separate community based upon the presence of Panicum havardii. In Texas, Sullivan described three communities in which Havard panicum was a major component. It is unclear whether this community is not as widely distributed in New Mexico as that reported in Texas or whether it was simply missed in the sampling process. The single stand was located in northern Chaves county in a rugged dune area with slopes greater than $30 \%$. 
Shinnery oak dominated the site with a canopy cover of $32 \%$, falling within the range reported for shinnery oak cover in Texas. species composition was similar between this study and that reported by sullivan, however, some variation occured in cover values. Little and sand bluestem were the primary grasses in the sample, with cover values of $4.9 \%$ and $2.4 \%$, respectively. Havard panicum cover was less than $1 \%$. Other common species included purple three-awn, sand paspalum, and sporobolus cryptandrus. The soil mapping unit was Roswell fine sand.

Prosopis glandulosa/Quercus havardii/Chloris cucullata-setaria macrostachya

This stand was unique in location and the species present. Located on the very western edge of the Llano Estecado in Chaves county, it appears to be a transitional area between a shinnery oak and mesquite grassland type. This stand was characterized by small mound shaped dunes covered by shinnery oak and grasses. Interdune space was vegetated primarily by mesquite.

This stand was among the most diverse sampled in both the number of species and variety of species. As previously noted, shinnery oak was localized on dune areas. Shinnery oak cover was $24 \%$ No grass clearly dominated in coverage, however, Chloris cucullata and Setaria macrostachya were most prominant. Both of these species had cover values of less than $2 \%$. Other common graminoids included Cenchrus incertus, Panicum obtusum, sporobolus contractus, sporobolus cryptandrus, and sporobolus flexuosus. Several forbs were also recorded in the stand, among the most 
common were Croton pottsii, Euphorbia spp., and Phyllanthus abnormis.

Prosopis glandulosa/Microhamnus ericoides-Quercus havardii/Aristida purpurea-sporobolus cryptandrus

Two stands were sampled within this community. Limited in area, this community appeared to be at the ecological limit of shinnery oak growth. Both stands were located in transitional areas between shinnery oak and mesquite communities. Stands were sampled in eastern Eddy county, but similar vegetation composition was observed in Chaves county.

These stands were characterized by an open mesquite canopy, with an understory of javelina bush, shinnery oak and several other woody species. Composition and coverage of grasses varied widely between sites. Purple three-awn was among the most prevelent at both sites, with cover ranging from approximately $2 \%$ to $7 \%$. other species present in both stands were: black grama, Panicum obtusum, and sand dropseed. Croton pottsii had a canopy of about $1 \%$ in the two stands.

Soils were unique among stands supporting shinnery oak, having caliche cobbles at the surface. Stands were located in Berino-Dune land complex and Kermit-Berino fine sands. Topography was level to gently sloping. 
BLM Library

Denver Federal Center

Bldg. 50, OC -521

POO. BOX 25047

Denver, CO 80225 